\title{
The Nexus between Gross Domestic Product (GDP) and Financial Performance of Firms: Empirical Evidence from the Nigerian Insurance Industry
}

\author{
Augustine Akande $^{1^{*}} \quad$ Sunday Eneojo Samuel ${ }^{2} \quad$ Elvis Udoh $^{3} \quad$ Ini E. Udofa ${ }^{4}$ \\ 1.Independent Researcher, AXA Nigeria - Lagos \\ 2.School of Business, Law and Social Sciences, Abertay University Dundee, United Kingdom \\ 3.Independent Researcher, AXA Nigeria - Lagos \\ 4.Department of Accounting, the University of Lagos
}

\begin{abstract}
This study looked at the impact of gross domestic products (GDP) on the Financial performance of insurance firms in Nigeria using gross written premium (GWP), profit before tax (PBT), total assets (TA), capital employed (CE) and shareholders fund (SHF) as proxies for financial performance. The study adopted the theories of shareholder primacy theory also known as the shareholder value theory and signalling theory. shareholder primacy theory sees organisation as entities with the primary objective of maximising the wealth of the shareholder while signalling theory looks at the propensity to change of financial performance to changes in GDP figures. Using secondary data sources, findings from the results of our regression analysis show that Nigeria's GDP has an impact on Total assets, total capital employed, profit before tax and shareholders fund but has negligible impact on the gross written premiums of insurance firms in Nigeria. It was therefore recommended that government should seek to contribute positively to GDP growth through the instrumentality of fiscal and monetary policies, enterprises should contribute to GDP growth through taxes and employee benefits and firms should adopt a bullish approach to consumption for better GDP outcomes.
\end{abstract}

Keywords: impact, gross domestic products, financial performance

DOI: $10.7176 / \mathrm{RJFA} / 12-6-07$

Publication date:March $31^{\text {st }} 2021$

\section{Introduction}

The $21^{\text {st }}$ century business environment places a demand on the managers of firms to adopt the stakeholders' approach in managing organisation. This approach enables an organisation to pay adequate attention to all its stakeholder, some of which are shareholders, management, employees, regulators, the society and suppliers.

Castelo (2013), argued that the primary reason for which an organisation exist is to meet and perhaps surpass the expectation of its shareholders. This construct situate corporate social responsibility within shareholder value maximisation. Organisations that take this approach to enterprise management seek to meet and surpass shareholder expectations, sometimes, at the expense of every other group not recognised as stakeholders within its construct.

The Bureau of Economic Analysis (BEA) defined Gross domestic product (GDP) as the value of the goods and services produced by the nation's economy less the value of the goods and services used up in production. GDP is also equal to the sum of personal consumption expenditures, gross private domestic investment, net exports of goods and services, and government consumption expenditures and gross investment (Karen \& Louise, 2018).

The gross domestic product (GDP) is an indicator of economic growth in that high GDP growth rates signals economic wellbeing of a country from a growth perspective. Conversely, negative growth rates in GDP signals economic retardation. Generally, economists believe that negative GDP growth rates for two consecutive quarters indicates economic recession. It appears therefore that increases in the gross domestic products of an economy may have a positive effect on the financial performance of firms. Conversely, decreases in the gross domestic product of an economy may have a negative effect on the financial performance of firms. This study attempts to find the relationship (if any) between the gross domestic products and the financial performance of firms.

\subsection{Statement of the Problem}

The prosperity of the world is to a large extent premised on the financial performance of corporations. Corporations not only create and sustain wealth for its shareholders, they also create employment opportunities, supply of contracts to contractors, provide revenue to government in the form of taxes and duties and improve societal wellbeing in the form of corporate social responsibilities. Evidently, these influences on the society by corporations create wealth for individuals, governmental institutions and investors and goes a long way to influence societal prosperity.

Stakeholders should therefore be interested in the financial performance of firms as much as the shareholders of those firms. Typically, firms do not operate in isolations, but operates in economies and are therefore affected 
by the happenings in the economy they operate in. One of the singular and comprehensive pointers to the health of an economy is the gross domestic product (GDP). growth rates of the gross domestic product connotes some positives for firms operating in that economy. It can be inferred therefore that economic growth or the lack of it affect corporations.

This study therefore attempts to identify the relationship between the gross domestic products (GDP) and the Financial Performance of firms.

\subsection{Objectives of the Study}

The Broad objective of the study is to assess the impact of Gross Domestic Products (GDP) and the Financial Performance of firms. The specific objectives of the study are;

i. To assess the impact of the Gross Domestic Products (GDP) on the Gross Written Premium (GPW) of insurance companies in Nigeria.

ii. To assess the impact of the Gross Domestic Products (GDP) on the Profit before Tax (PBT) of insurance companies in Nigeria.

iii. To assess the impact of the Gross Domestic Products (GDP) on the Total Assets (TA) of insurance companies in Nigeria.

iv. To assess the impact of the Gross Domestic Products (GDP) on the Capital Employed (CE) of insurance companies in Nigeria.

v. To assess the impact of the Gross Domestic Products (GDP) on the shareholders fund (SHF) of insurance companies in Nigeria.

\subsection{Research Hypothesis}

From the objectives of the study, the following research hypotheses, in null form, were developed:

i. There is no significant impact of the Gross Domestic Products (GDP) on the Gross Premium Written (GPW) of insurance companies in Nigeria.

ii. There is no significant impact of the Gross Domestic Products (GDP) on the Profit before Tax (PBT) of insurance companies in Nigeria.

iii. There is no significant impact of the Gross Domestic Products (GDP) on the Total Assets (TA) of insurance companies in Nigeria.

iv. There is no significant impact of the Gross Domestic Products (GDP) on the Capital Employed (CE) of insurance companies in Nigeria.

v. There is no significant impact of the Gross Domestic Products (GDP) on the Shareholders Funds (SHF) of insurance companies in Nigeria

\subsection{Literature Review}

\subsection{Conceptual Framework}

\subsection{Gross Domestic Products and Gross Written Premium}

Gross domestic products encapsulates the monetary value of the totality of goods and services produced in a country during a specific period. According to Augustine, Samuel and Iyodo (2020), Gross premiums written is the sum of both direct premiums written and assumed premiums written before the effect of ceded reinsurance. Direct premiums written represents the premiums on all policies the Company's insurance subsidiaries have issued during the year.

\subsubsection{Gross Domestic Products and Profit before Tax}

According to Augustine, Samuel and Iyodo (2020), Profit before tax (PBT) is a measure that looks at a company's profits before the company pay corporate income tax. It deducts all expenses from revenue including interest expenses and operating expenses except for income tax.

\subsection{Gross Domestic Products and Total Assets}

Total assets refers to the total amount of assets owned by a person or entity. Assets are items of economic value, which are expended over time to yield a benefit for the owner. If the owner is a business, these assets are usually recorded in the accounting records and appear in the balance sheet of the business.

\subsubsection{Gross Domestic Products and Capital Employed}

According to Augustine, Samuel and Iyodo (2020), Capital employed, also known as funds employed, is the total amount of capital used for the acquisition of profits by a firm or project. It is the value of all the assets employed in a business or business unit and can be calculated by adding Non-current assets to working capital or by subtracting current liabilities from total assets. By employing capital, you thus make an investment.

\subsection{Gross Domestic Products and Shareholders Funds}

Shareholders' funds refer to the amount of equity in a company, which belongs to the shareholders. The number of shareholders' funds yields an approximation of theoretically how much the shareholders would receive if a business were to liquidate. (Augustine, Samuel and Iyodo 2020). 


\subsection{Empirical Framework}

CEA, (2006) examined the Contribution of the Insurance Sector to Economic Growth and Employment in the EU and showed that the insurance industry plays a pivotal role in the implementation of the "Lisbon strategy" which is geared towards providing a competitive environment for employment growth and sustainable long term economic growth. The study opined that policy makers should be concerned if insurance contribution to total GDP dwindles and should promote policies that ensures that insurance contribution to GDP grows by promoting a principle-based regulatory regime. Similarly, Mirela Cristeaa, Nicu Marcua and Silviu Cârstina (2013), observed a correlation between economic development and insurance industry growth. The researchers observed that insurance contribution to GDP is around $10 \%$ in some European countries like Netherlands, the UK and Finland and get even higher proportionate with economic development. Using GDP per capita and the degree of insurance penetration, for the total insurance market, life insurance and non-life insurance, GDP per capita and insurance density, the degree of penetration of the insurance business with GDP growth and the real growth of insurance with GDP growth as research variables and linear regression statistical tool, the study established that there is a high correlation, based on the causal link, between the insurance market, measured by the degree of insurance penetration, and the degree of density and the economic growth, measured by GDP per capital. Li, Moshirian, Nguyen, and Wee, (2007) examined the Demand for Life Insurance in OECD Countries by looking at determinants of life insurance consumption in OECD countries, consistent with previous results, the researcher find a significant positive income elasticity of life insurance demand. Furthermore, as dependents and academic qualification increases, demand for life insurance increases, conversely, as life expectancy and social security expenditure increases, the demand for life insurance decreases. They concluded therefore that a country's level of financial development and its insurance market's degree of competition appear to stimulate life insurance sales, whereas high inflation and real interest rates tend to decrease consumption. Arena \& Marco (2008), using the generalized method of moments (GMM) on a panel data of 55 countries between 1976 and 2004, the researcher found a positive and significant causal relationship between life and nonlife insurance and economic growth. According to Tijani and Babajide (2015), examined the nexus between Economic Growth and Insurance Business in Nigeria, using economic growth as measured by the GDP as dependent variable and Insurance Activities (contribution of insurance sector to GDP), Inflation Rate (infrate) and Real Exchange Rate (rerate) as the Independent Variable, least square regression result show that the is a link between insurance and economic growth in Nigeria.

While there has been a lot of studies on the interplay between insurance activities and economic growth, no study has used gross premium written, profit before tax, total assets and capital employed as proxies for financial performance. Furthermore, the line between the impact of insurance activities on economic development and economic growth has been blurry with no distinction made between growth and development. CEA, (2006), Mirela Cristeaa, Nicu Marcua and Silviu Cârstina (2013), Silviu Cârstina (2013), Li, Moshirian, Nguyen, and Wee, (2007), Arena \& Marco (2008) \& Tijani and Babajide (2015). This study therefore examines the impact of the GDP (an indicator of economic growth) on the financial performance metrics of insurance firms.

\subsection{Theoretical Framework}

\subsubsection{Shareholder Primacy Theory/Shareholder Value Theory}

The shareholder primacy theory is also known as the shareholder value theory. It is consistent with existing theories on shareholders wealth maximization. According to the proponents of the theory, the primary objective of all profit-making organisations is to meet and strive to surpass the expectations of its shareholders, often expressed using financial indicators. Some of the financial indicators used by firms are revenue, profit before tax (PBT), total assets (TA), capital employed (CE), shareholders fund (SHF), profit after tax (PAT), return on assets, (ROA), return on equity (ROE), return on shareholders capital (ROSC), return on capital employed (ROCE), profit margins and earnings per share (EPS). (Akande, Samuel \& Iyodo 2020), (Adedeji, Babatunde \& Adekanye 2015), (Idris,2015) and (Imeokparia, 2014).

\subsubsection{Signalling Theory}

Ross (1977) promoted the signalling theory by disagreeing that firms would increase their total equity capital mix if they are positive about the future, thus increase their equity holding to signal their optimistic potentials for the future (Berger, 1995). The signalling theory therefore can be described as expressing the relationship between two variables where a change in one variable potentially signals a proportionate or disproportionate change in the other variable. For example, a change in the gross domestic product (GDP) could potentially trigger a change in financial metrics such as revenue, profit, profit margins and shareholders fund.

\subsection{Materials and Methods}

This study adopts the ex post facto research strategy. According to Samuel and Iyodo (2011), Adebisi and Samuel (2012), and Iyodo et al. (2020), ex post facto research is a systematic empirical study in which the researcher does not in any way control or manipulates the independent variables because the situation of study has already taken place. Furthermore, the study adopted the purposive sampling method to work out a sample size of 12 insurance 
companies contributing approximately $69 \%$ of the total insurance industry revenue over a ten years period from 2009 to 2018 . The choice of purposive sampling is to enable the researcher to get enough publicly obtainable information on the financial performances of selected insurance firms. Data for this study was from secondary sources through the instrument of documentation. Documented information majorly from the National Insurance Commission (NAICOM), The Nigerian Insurers Association (NIA), The Nigerian Stock exchange and company annual reports.

3.1 Variables and Definitions

\begin{tabular}{|c|c|c|}
\hline Variables & Description \& measurements & Source \\
\hline $\begin{array}{l}\text { Gross Domestic } \\
\text { Products (GDP) }\end{array}$ & $\begin{array}{l}\text { Defined as the value of the goods and services produced by } \\
\text { the nation's economy less the value of the goods and services } \\
\text { used up in production. }\end{array}$ & $\begin{array}{l}\text { Karen and Louise, } \\
(2018) \text {. }\end{array}$ \\
\hline $\begin{array}{l}\text { Gross } \quad \text { Premium } \\
\text { Written (GPW) }\end{array}$ & $\begin{array}{l}\text { Written premiums are the premiums registered on the books } \\
\text { of an insurer or reinsurer at the time a policy is issued and } \\
\text { paid for }\end{array}$ & $\begin{array}{l}\text { Gospel and Benson } \\
(2018)\end{array}$ \\
\hline $\begin{array}{l}\text { Profit before Tax } \\
\text { (PBT) }\end{array}$ & $\begin{array}{l}\text { Profit before tax (PBT) is a measure that looks at a company's } \\
\text { profits before the company must pay corporate income tax }\end{array}$ & Stephen et al (2018) \\
\hline Total Assets (TA) & $\begin{array}{l}\text { Total assets refer to the total amount of assets owned by a } \\
\text { person or entity. Assets are items of economic value, which } \\
\text { are expended over time to yield a benefit for the owner. If the } \\
\text { owner is a business, these assets are usually recorded in the } \\
\text { accounting records and appear in the balance sheet of the } \\
\text { business. }\end{array}$ & $\begin{array}{l}\text { Lateef, Babatunde } \\
\text { and } \\
\text { Adekanye (2015) }\end{array}$ \\
\hline $\begin{array}{l}\text { Capital Employed } \\
\text { (CE) }\end{array}$ & $\begin{array}{l}\text { Capital employed, also known as funds employed, is the total } \\
\text { amount of capital used for the acquisition of profits by a firm } \\
\text { or project. It is the value of all the assets employed in a } \\
\text { business or business unit and can be calculated by Non- } \\
\text { current assets to working capital or by subtracting current } \\
\text { liabilities from total assets. By employing capital, you thus } \\
\text { make an investment. }\end{array}$ & Imeokparia (2014) \\
\hline $\begin{array}{l}\text { Shareholders' } \\
\text { Funds (SHF) }\end{array}$ & $\begin{array}{l}\text { Shareholders' funds refer to the amount of equity in a } \\
\text { company, which belongs to the shareholder }\end{array}$ & $\begin{array}{l}\text { Imeokparia (2014), } \\
\text { Idris (2015), } \\
\text { Oloye \& osuma (2015) }\end{array}$ \\
\hline
\end{tabular}

Source - Adapted from Augustine, Samuel and Iyodo (2020).

\subsection{Model Specification}

Due to the nature of data being considered, linear regression model is considered a suitable methodology. It determines and measures the effects of the independent variables (GDP) on the dependent variables (Gross Premium Written (GWP), Profit before Tax (PBT), Total Assets (TA), Capital Employed (CE) and Shareholders Funds (SHF)). Having stated the theoretical background of the panel data analysis, the researcher presents the model as follows:

Gross Written Premium $=\beta_{0}+\beta_{1} *$ Gross Domestic Products $(G D P)$.....................

Profit before Tax $=\beta_{0}+\beta_{1}{ }^{*}$ Gross Domestic Products $(G D P)$........................ 3.2

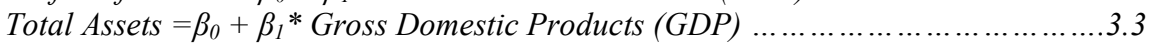

Capital Employed $(C E)=\beta_{0}+\beta_{1} *$ Gross Domestic Products $(G D P)$........................

Shareholders' Funds $(S H F)=\beta_{0}+\beta_{1}{ }^{*}$ Gross Domestic Products $(G D P)$....................... 3.4

Where:

$\beta_{0}$ : Slope

$\beta_{1}$ : Intercept of shareholder's fund 
4.0 Analysis and Discussion of Findings

4.1 Descriptive Statistics of Variables

\begin{tabular}{|l|l|l|l|l|l|l|}
\hline Summary Statistics & $\begin{array}{l}\text { Total GDP } \\
\text { (in millions } \\
\text { of Naira) }\end{array}$ & $\begin{array}{l}\text { Total } \\
\text { Assets (in } \\
\text { millions } \\
\text { of Naira) }\end{array}$ & $\begin{array}{l}\text { Total } \\
\text { GPW (in } \\
\text { millions } \\
\text { of Naira) }\end{array}$ & $\begin{array}{l}\text { Total } \\
\text { Capital } \\
\text { Employed } \\
\text { (in millions } \\
\text { of Naira) }\end{array}$ & $\begin{array}{l}\text { Total } \\
\text { PBT } \\
\text { millions } \\
\text { of Naira) }\end{array}$ & $\begin{array}{l}\text { Total } \\
\text { SHF } \\
\text { millions } \\
\text { of Naira) }\end{array}$ \\
\hline Number of samples & 10 & 10 & 10 & 10 & 10 & 10 \\
\hline Mean & $62,752,689$ & 376,253 & 153,354 & 236,339 & 14,507 & 118,453 \\
\hline Median & $65,185,754$ & 327,265 & 155,005 & 209,438 & 14,172 & 114,160 \\
\hline Standard Deviation & $6,962,975$ & 209,985 & 69,623 & 115,863 & 8,951 & 32,162 \\
\hline Sample Variance & $4.85 \times 10^{18}$ & $4.41 \times 10^{10}$ & $4.85 \times 10^{9}$ & $1.34 \times 10^{10}$ & $8.01 \times 10^{7}$ & $1.03 \times 10^{9}$ \\
\hline Kurtosis & -0.7122 & -0.8145 & -0.9924 & -0.1323 & 0.3090 & -0.6678 \\
\hline Skewness & -0.7575 & 0.6736 & 0.1586 & 0.9476 & 0.7617 & 0.7141 \\
\hline Range & $19,943,843$ & 594,480 & 207,266 & 332,956 & 28,436 & 90,797 \\
\hline Minimum & $49,856,099$ & 151,476 & 58,885 & 123,150 & 4,148 & 85,265 \\
\hline Maximum & $69,799,942$ & 745,956 & 266,151 & 456,106 & 32,584 & 176,062 \\
\hline Sum & $627,526,894$ & $3,762,532$ & $1,533,543$ & $2,363,391$ & 145,070 & $1,184,526$ \\
\hline Confidence Level $\mathbf{( 9 5 . 0 \% )}$ & $4,981,012$ & 150,214 & 49,806 & 82,883 & 6,403 & 23,007 \\
\hline
\end{tabular}

Table 4.1: Summary statistics of variables

As observed in table 4.1 above, there are 10 observations for each variable, the mean of each variable is shown in Figure 1 above, it is observed that all the variables have kurtosis values that are lesser than 3 meaning that they have lighter tails and do not contain outliers. Also, the following variables: total GDP, total assets, total capital employed, total PBT and total SHF all have skewness values that fall between -0.5 and +0.5 which means that their respective data are fairly symmetrical, the skewness value of the total GPW variable falls below that limit and its skewed to the right (i.e. positively skewed). The standard deviations values of each of the variables as shown in table 4.1 are spread on each side of their respective means.

\subsection{Regression Results:}

\subsubsection{Model 1 (Total Assets and GDP)}

\begin{tabular}{|c|c|c|c|c|c|c|}
\hline \multicolumn{2}{|l|}{ Regression Statistics } & & & & & \\
\hline Multiple R & 0.858133468 & & & & & \\
\hline R Square & 0.736393049 & & & & & \\
\hline Adjusted R Square & 0.70344218 & & & & & \\
\hline Standard Error & 114351853.4 & & & & & \\
\hline Observations & 10 & & & & & \\
\hline ANOVA & df & SS & MS & $\mathbf{F}$ & Significance $\mathbf{F}$ & \\
\hline Regression & 1 & $2.92233 \times 10^{17}$ & $2.92 \times 10^{17}$ & 22.34821 & 0.001487922 & \\
\hline Residual & 8 & $1.04611 \times 10^{17}$ & $1.31 \times 10^{17}$ & & & \\
\hline \multirow[t]{2}{*}{ Total } & 9 & $3.96844 \times 10^{17}$ & & & & \\
\hline & Coefficients & Standard Error & t Stat & P-value & Lower 95\% & Upper 95\% \\
\hline Intercept & -1247727446 & 345423885.6 & -3.61216 & 0.00686 & -2044276355 & -451178537.6 \\
\hline Total GDP (in millions of Naira) & 25.87906101 & 5.4742813 & 4.72739 & 0.001488 & 13.25534569 & 38.50277632 \\
\hline
\end{tabular}

Table 4.2.1: Regression Statistics and results of Total Assets owned by Insurance Firms vs Nigeria's GDP

A simple linear regression was calculated to predict total assets based on GDP as shown in table $4.2 \&$ figure 4.1. From the results in table, the correlation between total assets and GDP is $85 \%$ hinting that there is a strong positive correlation between total assets owned by insurance companies in Nigeria and the nation's GDP. The coefficient of determination $\left(\mathrm{R}^{2}\right)$ value is 0.736 , this further reaffirms the strong positive relationship between both variables and as such, it tells us that about $73.6 \%$ of the variation in total assets owned by Nigerian insurance firms can be explained by the nation's GDP.

The value of the standard error of the regression tells us that the standard distance between the observed total assets value and that predicted by the regression line is 114 trillion Naira.

From the model (total assets vs GDP), it is observed that the p-value from the Analysis of Variance table below is approximately 0.001 which is lower than 0.05 and as such, the null hypothesis can be rejected, which means there is significant relationship between total assets owned by Nigerian insurance firms and the GDP of the nation at any significant level. 


\subsubsection{Model 2 (GPW and GDP)}

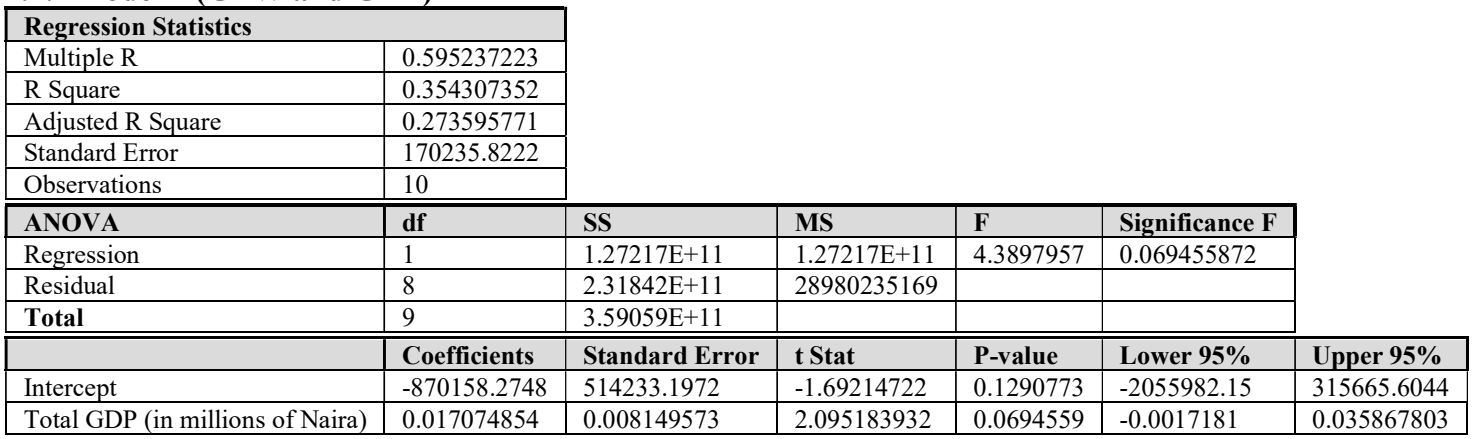

Table 4.2.2: Regression Statistics and results of GPW owned by Insurance Firms vs Nigeria's GDP

From the results in table 4.2.2 above, the correlation between total gross premium written by insurance companies in Nigeria and GDP is about $59.5 \%$ which means that there is a positive correlation between both variables. The coefficient of determination $\left(\mathrm{R}^{2}\right)$ value is 0.3543 , this hints at a weak positive relationship between both variables and as such, it tells us that only about $35 \%$ of the variation in total gross premium written by insurance companies in Nigeria can be explained by the nation's GDP.

The value of the standard error of the regression tells us that the standard distance between the observed total gross premium written value and that predicted by the regression line is $\mathbf{1 7 0}$ billion Naira.

From the model (i.e. GPW vs GDP), it can be seen that the p-value from the Analysis of Variance table below is approximately 0.07 , is higher than 0.05 therefore, we fail to reject the null hypothesis and conclude that there is no significant relationship between the total gross premium written by insurance companies in Nigeria and the GDP of the nation at any significant level.

\subsubsection{Model 3 (Total Capital Employed and GDP)}

\begin{tabular}{|c|c|c|c|c|c|c|}
\hline \multicolumn{2}{|l|}{ Regression Statistics } & & & & & \\
\hline Multiple R & 0.981184695 & & & & & \\
\hline R Square & 0.962723406 & & & & & \\
\hline Adjusted R Square & 0.958063831 & & & & & \\
\hline Standard Error & 23726.70098 & & & & & \\
\hline Observations & 10 & & & & & \\
\hline ANOVA & df & SS & MS & $\mathbf{F}$ & Significance F & \\
\hline Regression & 1 & $1.16313 \mathrm{E}+11$ & $1.16313 \mathrm{E}+11$ & 206.6118799 & $5.36023 \mathrm{E}-07$ & \\
\hline Residual & 8 & 4503650715 & 562956339.3 & & & \\
\hline Total & 9 & $1.20817 \mathrm{E}+11$ & & & & \\
\hline & Coefficients & Standard Error & t Stat & P-value & Lower 95\% & Upper 95\% \\
\hline Intercept & 1260884.623 & 71671.50335 & 17.59255162 & $1.11347 \mathrm{E}-07$ & 1095609.84 & 1426159.406 \\
\hline $\begin{array}{l}\text { Total GDP (in millions of } \\
\text { Naira) }\end{array}$ & -0.016326718 & 0.001135851 & -14.3740001 & $5.36023 \mathrm{E}-07$ & -0.018945995 & -0.01370744 \\
\hline
\end{tabular}

Table 4.2.3: Regression Statistics and results of Capital Employed by Insurance Firms vs Nigeria's GDP

From the results in table 4.2.3, the correlation between capital employed by insurance companies in Nigeria and GDP is about $98 \%$ which suggest a strong positive correlation between both variables. The coefficient of determination $\left(\mathrm{R}^{2}\right)$ value is about 0.962 , this further reaffirms the strong positive relationship between both variables and as such, it tells us that about $96 \%$ of the variation in total capital employed by insurance companies in Nigeria can be explained by the nation's GDP.

The value of the standard error of the regression tells us that the standard distance between the observed total capital employed by insurance companies in Nigeria value and that predicted by the regression line is 23.7 billion Naira.

From the model (i.e. total capital employed vs GDP), it can be seen that the p-value from the Analysis of Variance table below is approximately $5.36 \times 10^{-07}$ which is far below 0.05 and as such, the null hypothesis can be rejected, which means there is significant relationship between total capital employed by insurance companies in Nigeria and the GDP of the nation at any significant level. 


\subsubsection{Model 4 (Profit Before Tax and GDP)}

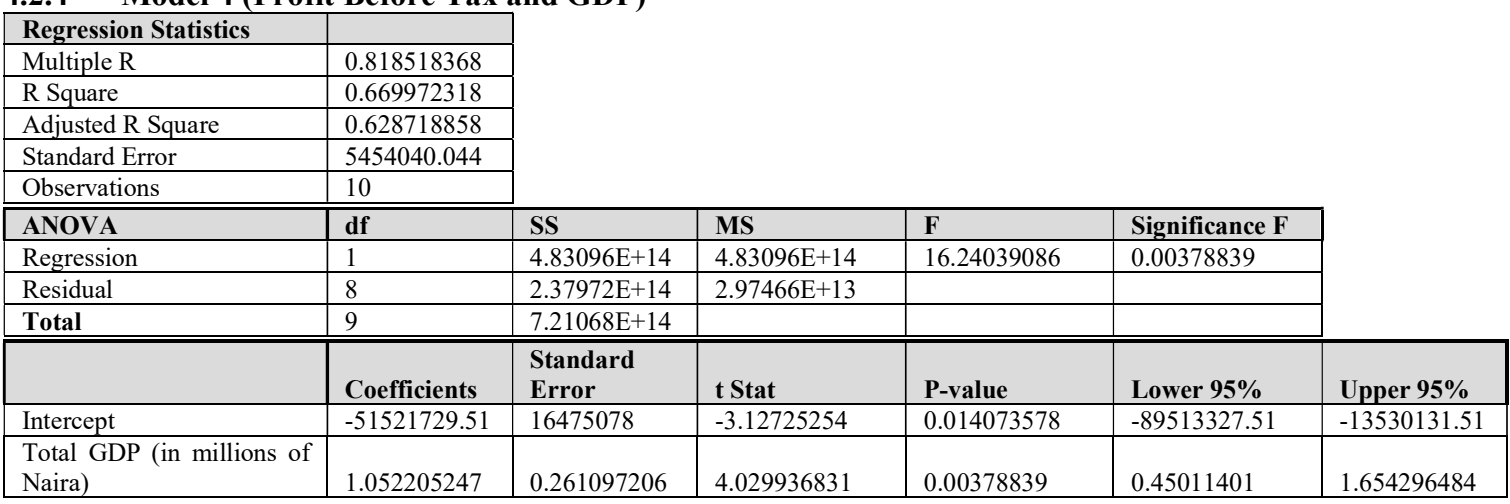

Table 4.2.4: Regression Statistics and results of profit before tax of Nigerian Insurance Firms vs Nigeria's GDP

From the results in table 4.2.4, the correlation between total profit before tax of Nigerian insurance firms and the nation's GDP is about $82 \%$ hinting that there is a strong positive correlation between both variables. The coefficient of determination $\left(\mathrm{R}^{2}\right)$ value is 0.669 , this mean there is a positive relationship between both variables; about $67 \%$ of the variation in total profit before tax of Nigerian insurance firms can be explained by the nation's GDP.

The value of the standard error of the regression tells us that the standard distance between the observed total assets value and that predicted by the regression line is about $\mathbf{5 . 4 5}$ trillion Naira.

From the model (total profit before tax vs GDP), it is observed that the p-value from the Analysis of Variance table above is approximately 0.004 which is lower than 0.05 and as such, the null hypothesis can be rejected, therefore, there is significant relationship between total profit before tax of Nigerian insurance firms and the GDP of the nation at any significant level.

\subsubsection{Model 5 (Shareholders Fund and GDP)}

\begin{tabular}{|c|c|c|c|c|c|c|}
\hline Regression Statistics & & & & & & \\
\hline Multiple R & 0.847262002 & & & & & \\
\hline R Square & 0.717852901 & & & & & \\
\hline Adjusted R Square & 0.682584513 & & & & & \\
\hline Standard Error & 18119.94232 & & & & & \\
\hline Observations & 10 & & & & & \\
\hline ANOVA & df & SS & MS & $\mathbf{F}$ & Significance F & \\
\hline Regression & 1 & 6682877160 & 6682877160 & 20.35400405 & 0.001971796 & \\
\hline Residual & 8 & 2626658478 & 328332309.7 & & & \\
\hline Total & 9 & 9309535637 & & & & \\
\hline & Coefficients & $\begin{array}{l}\text { Standard } \\
\text { Error }\end{array}$ & t Stat & P-value & Lower 95\% & Upper $95 \%$ \\
\hline Intercept & -127130.2483 & 54735.10658 & -2.32264549 & 0.048717818 & -253349.6304 & -910.8662259 \\
\hline $\begin{array}{l}\text { Total GDP (in millions of } \\
\text { Naira) }\end{array}$ & 0.003913503 & 0.000867443 & 4.511541205 & 0.001971796 & 0.001913177 & 0.005913829 \\
\hline
\end{tabular}

Table 4.2.5: Regression Statistics and results of Total shareholders fund of Nigerian Insurance Firms vs Nigeria's GDP

From the results table 4.2.5 above, the correlation between total shareholders fund of Nigerian Insurance Firms and GDP is $84.7 \%$ hinting that there is a strong positive correlation between both variables. The coefficient of determination $\left(\mathrm{R}^{2}\right)$ value is approximately 0.72 , this further reaffirms the strong positive relationship between both variables and as such, it tells us that about $72 \%$ of the variation in total shareholders fund of Nigerian Insurance Firms can be explained by the nation's GDP.

The value of the standard error of the regression tells us that the standard distance between the observed total assets value and that predicted by the regression line is about 18 billion Naira.

From the model (shareholders fund vs GDP), it can be seen that the p-value from the Analysis of Variance table below is approximately 0.002 which is lower than 0.05 and as such, the null hypothesis can be rejected, which means there is significant relationship between total shareholders fund of Nigerian Insurance Firms and the GDP of the nation at any significant level.

\subsection{Conclusion and Recommendations}

From the results of our regression analysis, we can see that Nigeria's GDP has an impact on Total assets, total capital employed, profit before tax and shareholders fund but has negligible impact on the gross written premiums of insurance firms in Nigeria.

Following the findings of the research, it is recommended that; 
Organisations should contribute maximally to the total GDP growth of its host countries through payment of taxes to government and salaries and pecuniary benefits to employees as the study suggest that such contributions ultimately impact organisational financial performance positively.

Governments should boost GDP growth as much as possible through the instrumentalities of fiscal and monetary policies.

Economic units (households and firms) should adopt a bullish approach to consumption for better GDP outcomes.

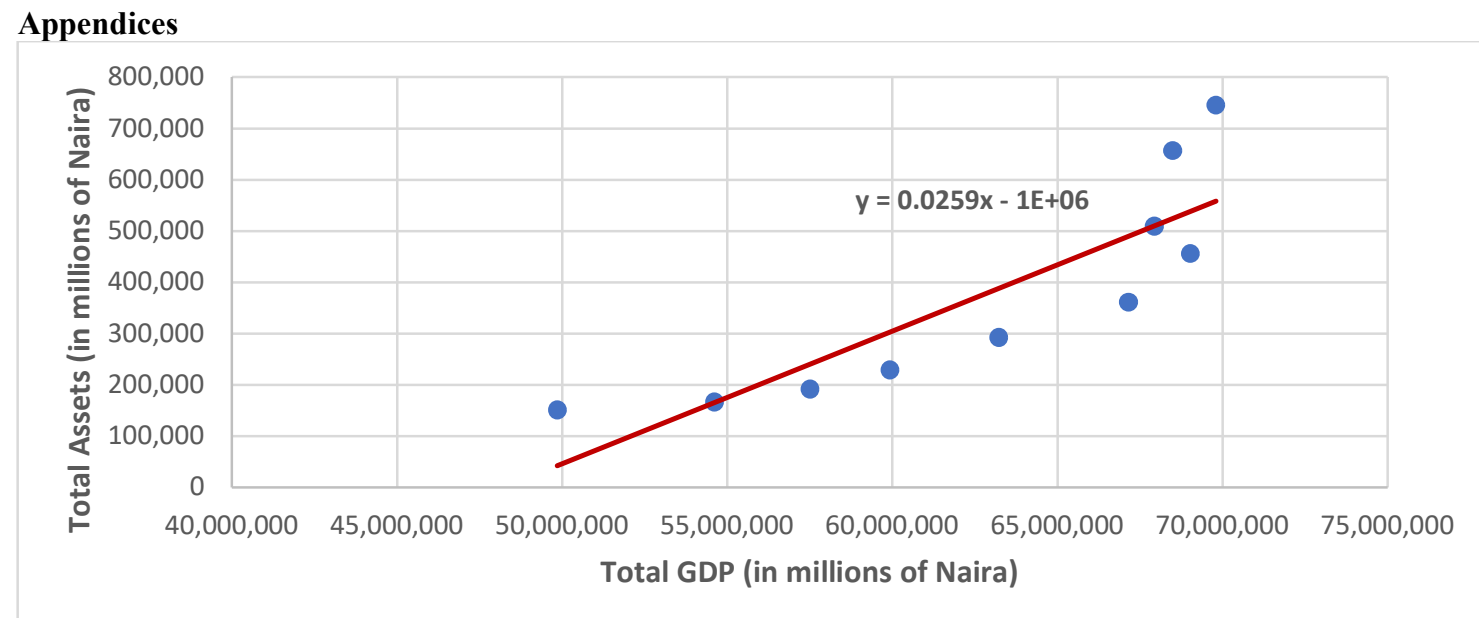

Figure 4.1: Regression Line plot for Total Assets as response variable vs Total GDP as explanatory variable

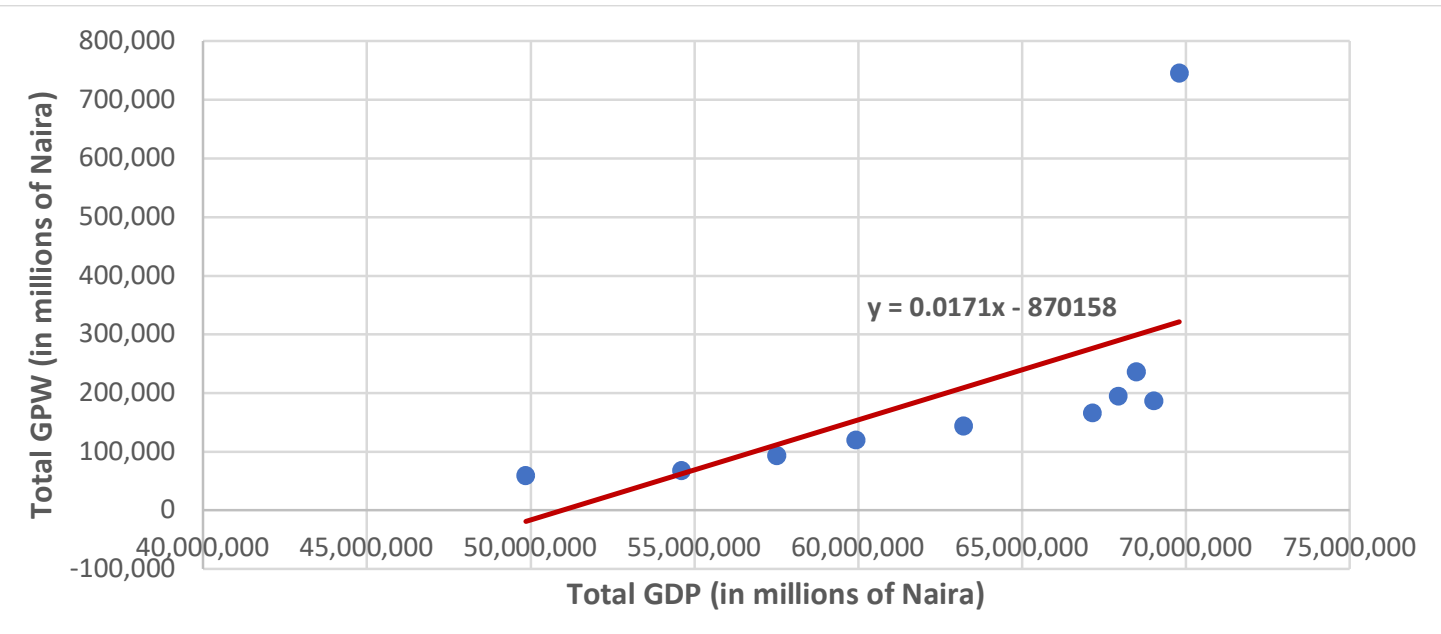

Figure 4.2: Regression Line plot for GPW as response variable vs Total GDP as explanatory variable 


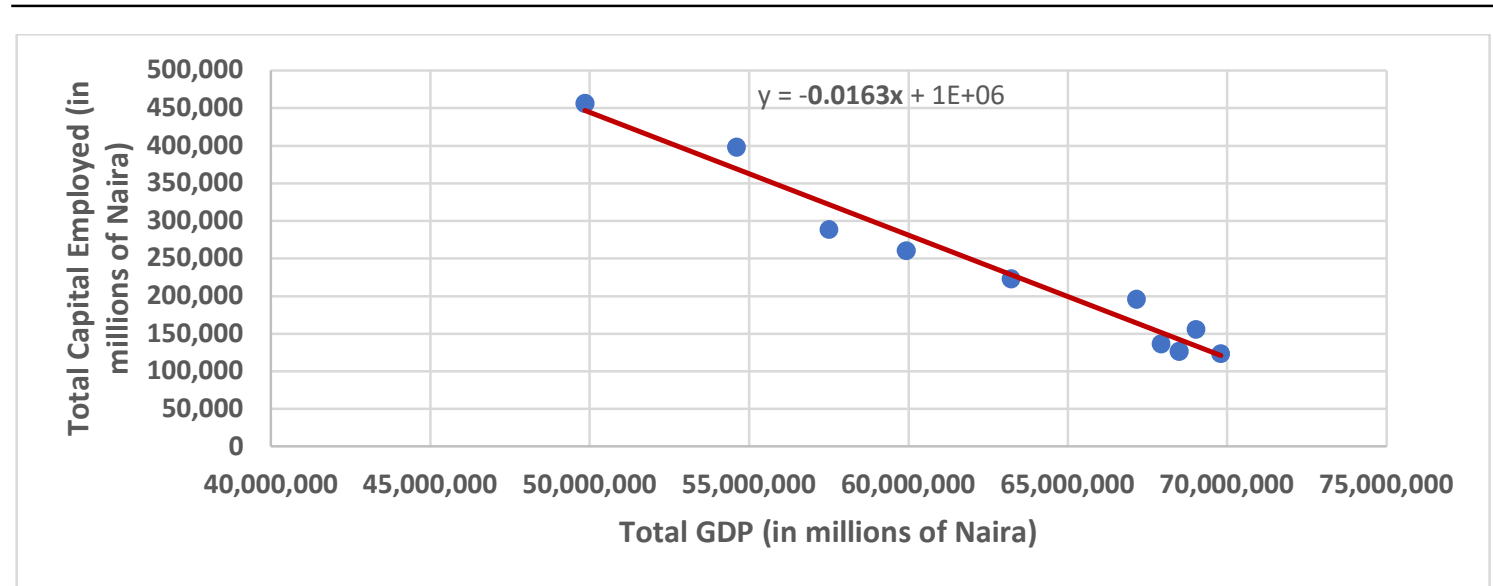

Figure 4.3: Regression Line plot for Total Capital Employed as response variable vs Total GDP as explanatory variable

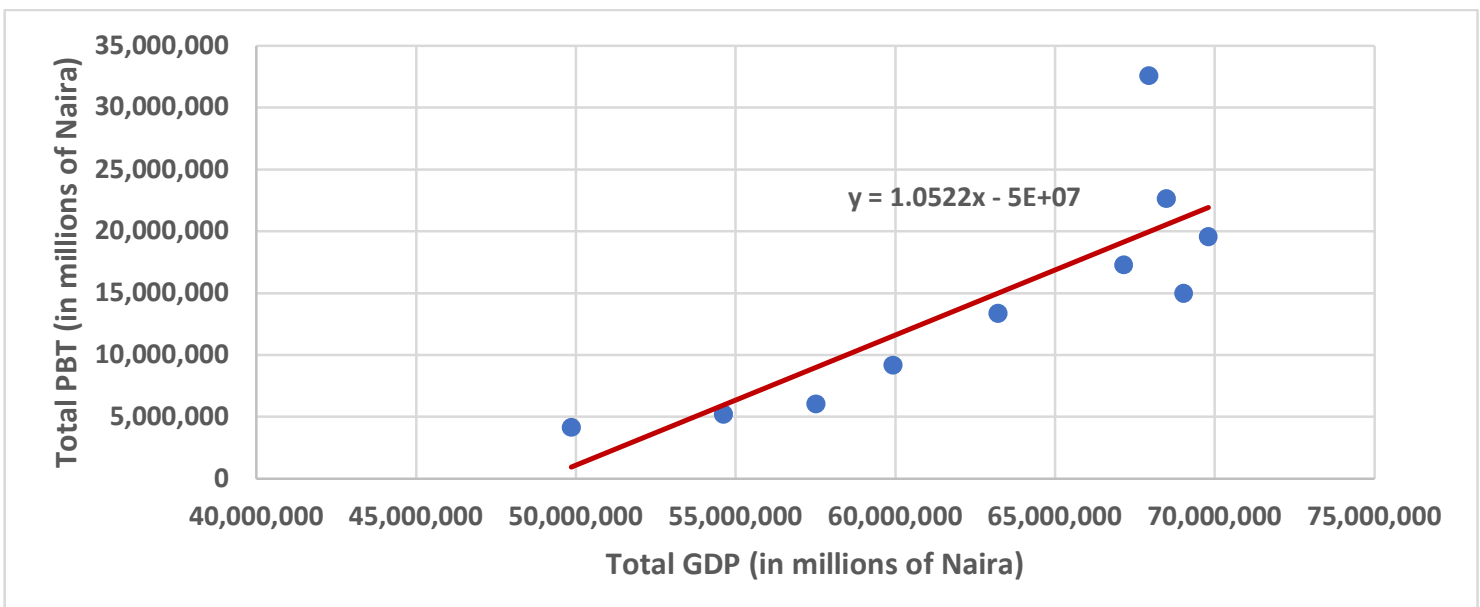

Figure 4.4: Regression Line plot for Total PBT as response variable vs Total GDP as explanatory variable

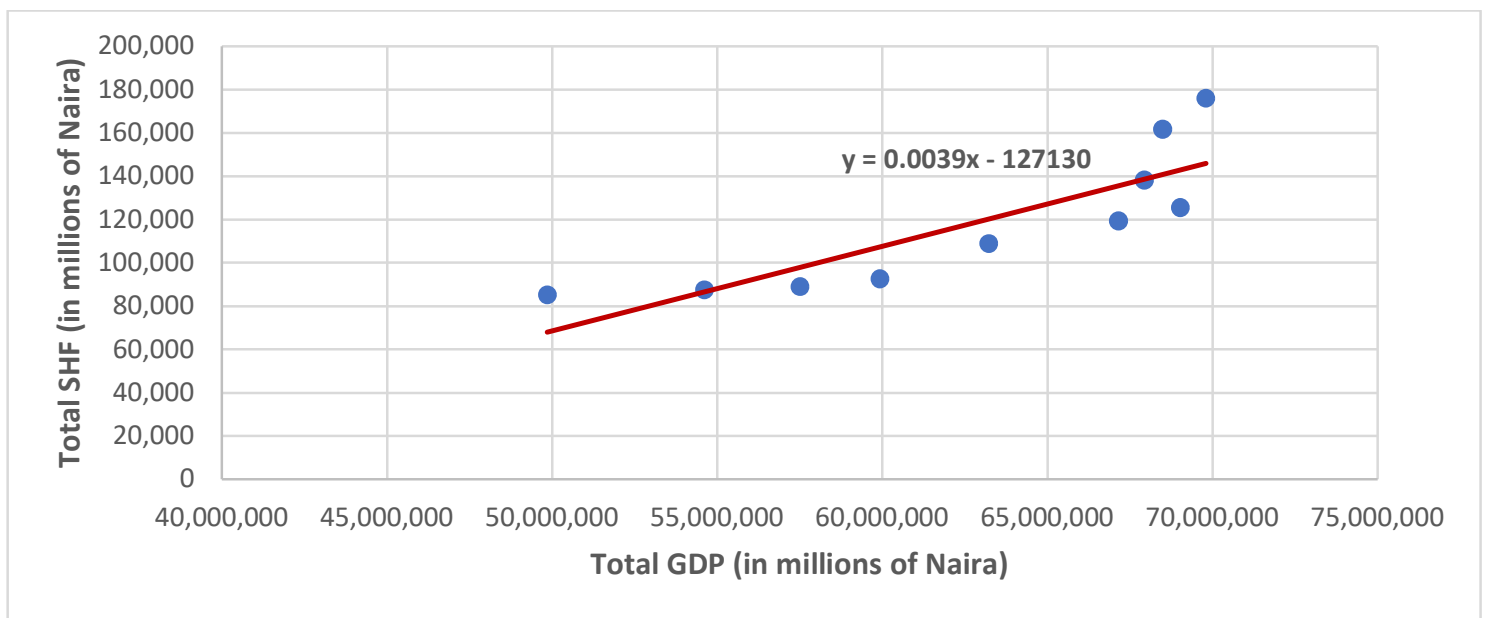

Figure 4.5: Regression Line plot for Total SHF as response variable vs Total GDP as explanatory variable

\section{Bibliography}

Akande, A.S., Samuel, S.E. and Iyodo, B.Y. (2020). Recapitalisation and the Financial Performance of Firms: Empirical Evidence from the Insurance Industry in Nigeria. European Journal of Business and 
Management.Vol. 12 No.23, pp.59-68, August. ISSN: 2222-2839

Adebisi, J.F. and Samuel, S.E. (2012). Effects of taxes on a dividend payout ratio of banks in Nigeria. Salem Journal of Management Science, 1(1): 88-106.

Adedeji, O.L., Babatunde, M.A. and Adekanye, T. (2015). Recapitalization policy and performance of banks in Nigeria. International Journal of Economics, Commerce and Management, 3(4): 1- 12.

Arena, Marco, 2008, Does Insurance Market Activity Promote Economic Growth? A Cross-Country Study for Industrialized and Developing Countries, Journal of Risk and Insurance, Vol 75, No. 4, p. 921-946

Berger, A.N. (1995). The profit-structure relationship in banking-tests of market-power and efficient-structure hypotheses. Journal of Money, Credit and Banking. 27(2):404-431

Castelo B.M. (2013) Shareholder Theory. In: Idowu S.O., Capaldi N., Zu L., Gupta A.D. (eds) Encyclopedia of Corporate Social Responsibility. Springer, Berlin, Heidelberg. https://doi.org/10.1007/978-3-642-28036$8 \_31$

CEA, 2006. Insurers of Europe, "The Contribution of the Insurance Sector to Economic Growth and Employment in the EU', Brussels.

Gospel, J. and Benson, P. (2018). Stakeholders satisfaction and performance of insurance firms in Nigeria. Journal of Economics and Finance, 9(6):6 -13.

Imeokparia, L. (2014). Post-merger acquisition and performance of deposit money banks in Nigeria. Journal of Business Management, 16(5): 18 -25.

Tijani M.O. \& Babajide D.A., (2015). Nexus between Economic Growth and Insurance Business in Nigeria. Research Journal of Finance and Accounting, 6(9): $142-149$.

Karen D., Louise S., (2018). GDP as a Measure of Economic Well-being. Hutchins Center on Fiscal and Monetary Policy at Brookings

Li, Moshirian, Nguyen, and Wee, 2007, "The Demand for Life Insurance in OECD Countries," Journal of Risk and Insurance, Vol 74, No. 3, p. 637-652.

Mirela Cristeaa, Nicu Marcua and Silviu Cârstina (2013). The relationship between insurance and economic growth in Romania compared to the main results in Europe - a theoretical and empirical analysis, 1st International Conference 'Economic Scientific Research - Theoretical, Empirical and Practical Approaches', ESPERA 2013 P. 226 - 235.

Ross (1977) Testing the Pecking Order Theory and the Signaling Theory Approach.” the Bell Journal of Economics 8 (1977): 23-40.

Oloye, M.I. and Osuma, G. (2015). Impact of mergers and acquisition on the performance of Nigerian banks. Journal of business and finance management research, 1(4):23-40.

Outreville, J.F, 1990. The Economic Significance of Insurance Markets in Developing Countries, The Journal of Risk and Insurance, Vol. 57, No.3, p. 487-498.

Stephen, Y., Hanania, D., Eric, B.Y. and Mark, K. (2018). Bank recapitalization in Ghana, who benefit the more? Global journal of management \& business research, 18 (6): 1-11. 